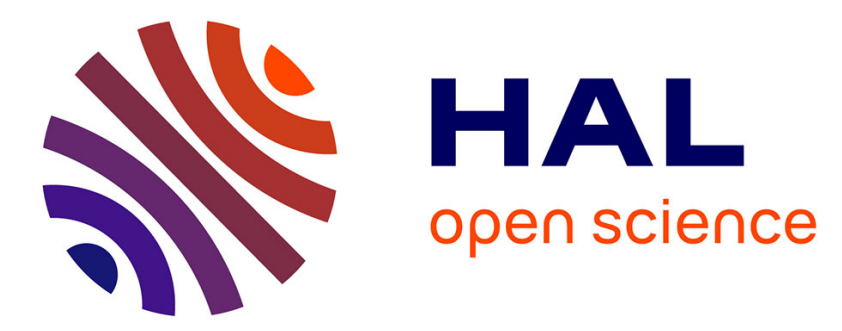

\title{
Apparent digestibilities of feed components from fish meal or plant protein based diets in common carp as affected by water temperature
}

\author{
J.D. Kim, Jeanine Breque, Sadasivam S. Kaushik
}

\section{To cite this version:}

J.D. Kim, Jeanine Breque, Sadasivam S. Kaushik. Apparent digestibilities of feed components from fish meal or plant protein based diets in common carp as affected by water temperature. Aquatic Living Resources, 1998, 11 (4), pp.269-272. hal-02687268

\section{HAL Id: hal-02687268 \\ https://hal.inrae.fr/hal-02687268}

Submitted on 1 Jun 2020

HAL is a multi-disciplinary open access archive for the deposit and dissemination of scientific research documents, whether they are published or not. The documents may come from teaching and research institutions in France or abroad, or from public or private research centers.
L'archive ouverte pluridisciplinaire HAL, est destinée au dépôt et à la diffusion de documents scientifiques de niveau recherche, publiés ou non, émanant des établissements d'enseignement et de recherche français ou étrangers, des laboratoires publics ou privés. 


\title{
Apparent digestibilities of feed components from fish meal or plant protein based diets in common carp as affected by water temperature
}

\author{
Jeong Dae $\operatorname{Kim}^{(1)}$, Jeanine Breque ${ }^{(2)}$, Sadasivam J. Kaushik ${ }^{(2)}$ \\ (1) Department of Animal Science, Kangwon National University, Chuncheon 200-701, Korea. \\ (2) Laboratoire de nutrition des poissons, Unité mixte Inra-Ifremer, 64310 Saint Pée-sur-Nivelle, France.
}

Received January 9, 1998; accepted August 27, 1998.

\begin{abstract}
Apparent digestibility coefficients (ADCs) of macro- and micronutrients and energy of two diets were measured with common carp Cyprinus carpio reared at two water temperatures $\left(18\right.$ and $\left.25^{\circ} \mathrm{C}\right)$. Two diets containing either soy protein concentrate (SPC) or Norwegian herring meal (FM) as a major protein source were formulated. Dicalcium phosphate was incorporated at a level of $4 \%$ of the former diet. Duplicate groups of 20 fish (body weight: $55 \mathrm{~g}$ ) were fed by hand twice a day to apparent satiety. After a 7-day conditioning period, faecal collection was made over 10 days using an automatic faeces collector. ADC of dry matter was not different $(P>0.05)$ between fish fed the two diets at $18^{\circ} \mathrm{C}$, but at $25^{\circ} \mathrm{C}$, we observed a higher ADC value in fish fed the FM diet than in those fed the SPC diet. ADC of protein was higher in fish fed the SPC diet than in the FM groups at either temperature. ADC of lipids was not different between the two groups at $25^{\circ} \mathrm{C}$ but was found to be higher in fish fed the SPC diet than in the FM group at $18^{\circ} \mathrm{C}$. ADCs of energy and ash of the two fish groups remained constant at both water temperatures. Availability of phosphorus was significantly higher $(P<0.05)$ from fish meal based diets than from SPC based diets at both temperatures. A more striking effect of dietary protein source was found in the availability of calcium, which was lower in carp fed SCP based diets. (O) Ifremer/ Elsevier, Paris
\end{abstract}

Digestibility / temperature / protein / lipid / calcium / phosphorus / Cyprinus carpio

\section{INTRODUCTION}

Fish are poikilothermic animals for which maximum growth and feed utilisation could be achieved only under optimal rearing temperature. For warmwater fish, such as the common carp, Cyprinus carpio, the water temperature ranges from 20 to $30^{\circ} \mathrm{C}$ for optimal growth. Although it is generally accepted that temperature has little effect on nutrient digestibility of fish [10], a decrease below optimal temperature would result in a reduction in feed intake and possibly affect digestibility. Total replacement of dietary fish meal by plant protein source such as soybean meal causes depressed growth, even when duly supplemented with essential amino acids $[1,16]$. Since supplemented amino acids are generally well absorbed by carp [14], the reduced growth with plant protein based diets might be due to a lack of available phosphorus level in such diets [10], because carp do not use well phosphorus from animal and plant origin [11]. To date, a number of digestibility trials using carp were devoted to investigating the availability of macronutrients and energy $[7,11,15]$. However, a comparison of macroand microelements and energy digestibilities has not been made using practical diets with carp held in different water temperatures. This experiment was conducted to compare digestibility coefficients of such components and energy of fish fed diets based on fish meal and soy protein concentrate as the major protein source at two rearing water temperatures.

* Corresponding author, e-mail: jdekim@cc.kangwon.ac.kr 


\section{MATERIALS AND METHODS}

\subsection{Experimental diets}

Two diets containing either $32 \%$ soy protein concentrate (SPC) or $30 \%$ Norwegian herring meal (FM) as a major protein source were formulated (table I). Reagent grade dicalcium phosphate of $4 \%$ was incorporated into the former diet. Diets were granulated into $2.5 \mathrm{~mm}$ diameter using an experimental compression pellet machine. Ingredient composition of the diets is reported in table $I$.

Table I. Feed ingredients and chemical composition of the experimental diets. SPC, soy protein concentrate; FM, Norwegian herring meal.

\begin{tabular}{lrr}
\hline Ingredient & SPC & FM \\
\hline CaHPO $_{4}, 2 \mathrm{H}_{2} \mathrm{O}$ & 4.0 & \\
Norwegian herring meal & - & 30.0 \\
Soy protein concentrate (SPC) & 32.0 & - \\
Corn gluten & 10.0 & 10.0 \\
Fish oil & 12.0 & 10.0 \\
Extruded peas & 25.0 & 33.0 \\
Soybean meal & 15.0 & 15.0 \\
$\mathrm{Vit}^{\mathrm{M} \text { Min. mix }}{ }^{1}$ & 2.0 & 2.0 \\
$\mathrm{Cr}_{2} \mathrm{O}_{3}$ & 1.0 & 1.0 \\
$\mathrm{Chemical}$ composition (g or $\mathrm{kJ} / 100 \mathrm{~g} \mathrm{DM})$ & & \\
$\mathrm{C}$. protein & 40.6 & 41.4 \\
$\mathrm{C}$. lipid & 12.6 & 13.4 \\
$\mathrm{C}$. ash & 9.3 & 9.1 \\
$\mathrm{Ca}$ & 2.3 & 2.8 \\
$\mathrm{P}$ & 1.6 & 1.3 \\
Energy $_{\mathrm{Cr}} \mathrm{O}_{3}$ & 2102.0 & 2144.0 \\
\hline
\end{tabular}

'Kaushik et al. [9].

\subsection{Digestibility measurements}

Common carps with an average body weight of $55 \mathrm{~g}$ were randomly allotted to conical-bottomed tanks (vol. $60 \mathrm{~L}$ ) supplied with recirculated water of $18{ }^{\circ} \mathrm{C}$. Duplicate groups of 20 fish were fed twice a day by hand to apparent satiation. After a 7-day conditioning period, faeces collection was made every morning, before the first meal, for 10 days using an automatic faeces collector [6]. After final collection of faeces, the water temperature was increased to $25^{\circ} \mathrm{C}$ by one degree per day. Under this temperature condition, fish were adapted for 7 days and diets were fed twice a day, and then faeces were collected for 10 days.

\subsection{Analytical methods}

The chemical composition of the experimental diets and faeces was determined using the following procedures [2]: dry matter by drying in an oven at $110^{\circ} \mathrm{C}$ for $24 \mathrm{~h}$; crude protein $(\mathrm{N} \times 6.25)$ by the Kjeldahl method after acid digestion; lipid fat after ether extraction by the Soxhlet method; ash by incineration in a muffle furnace at $550^{\circ} \mathrm{C}$ for $24 \mathrm{~h}$, Ca by a wet ash method and titration with $\mathrm{KMnO}_{4}$ and $\mathrm{P}$ by the vanado-molybdate method. Chromic oxide in the diet and faeces was analysed using a spectrophotometer (Beckman Model25) at a wave length of $440 \mathrm{~nm}$ after perchloric acid digestion [3]. Gross energy was determined using an adiabatic bomb calorimeter. Statistical analyses were performed by using analysis of variance and the multiple range test of Duncan [8] at the $5 \%$ probability level.

\section{RESULTS AND DISCUSSION}

Chemical composition of faeces is shown in table II. Protein in $100 \mathrm{~g}$ dry faeces was 13.8 and $23.9 \mathrm{~g}$ at $18^{\circ} \mathrm{C}$ which decreased to 10.7 and $19.2 \mathrm{~g}$ at $25^{\circ} \mathrm{C}$ for SPC and FM groups, respectively. Lipid was also higher in the faeces of fish fed diet FM than in those fed diet SPC at $18^{\circ} \mathrm{C}$, and was reduced to $1.96 \mathrm{~g}$ in the former groups and $2.40 \mathrm{~g}$ in the latter groups at $25^{\circ} \mathrm{C}$. Ash content was not different at $18^{\circ} \mathrm{C}$, while at the higher temperature, ash content in fish fed diet FM was significantly higher. The same trend was found for $\mathrm{Ca}$ content; however, faecal $P$ content was lowest in fish fed diet $F M$ at $18^{\circ} \mathrm{C}$. Energy in faeces was highest $\left(16.18 \mathrm{~kJ} \cdot \mathrm{g}^{-1}\right)$ in fish fed diet $\mathrm{FM}$ in $18^{\circ} \mathrm{C}$.

Apparent digestibility coefficients (ADCs) of feed components are presented in table III. At $18^{\circ} \mathrm{C}$, ADC of dry matter did not vary between diets, while fish fed diet FM showed an increase $(P<0.05)$ in the ADC of

Table II. Chemical composition of faeces collected under two different temperatures ${ }^{1}$. SPC, soy protein concentrate; FM, Norwegian herring meal.

\begin{tabular}{|c|c|c|c|c|}
\hline \multirow{2}{*}{$\begin{array}{l}\text { Composition } \\
\text { (g or } \mathrm{kJ} / 100 \mathrm{~g} \mathrm{DM})\end{array}$} & \multicolumn{2}{|c|}{ Diet $/ 18^{\circ} \mathrm{C}$} & \multicolumn{2}{|c|}{ Diet $/ 25^{\circ} \mathrm{C}$} \\
\hline & SPC & FM & SPC & FM \\
\hline Protein & $13.8^{\mathrm{c}}$ & $23.9^{\mathrm{a}}$ & $10.7^{\mathrm{d}}$ & $19.2^{\mathrm{b}}$ \\
\hline Lipid & $2.7^{b}$ & $5.6^{\mathrm{a}}$ & $2.0^{\mathrm{b}}$ & $2.4^{\mathrm{b}}$ \\
\hline Ash & $27.1^{\mathrm{b}}$ & $26.5^{\mathrm{b}}$ & $28.0^{\mathrm{b}}$ & $31.7^{\mathrm{a}}$ \\
\hline $\mathrm{Ca}$ & $7.5^{\mathrm{bc}}$ & $8.1^{\mathrm{b}}$ & $7.1^{\mathrm{c}}$ & $9.0^{\mathrm{a}}$ \\
\hline$P$ & $4.3^{\mathrm{a}}$ & $3.4^{\mathrm{b}}$ & $4.5^{\mathrm{a}}$ & $4.2^{\mathrm{a}}$ \\
\hline Energy & $1407^{b}$ & $1618^{4}$ & $1393^{\mathrm{b}}$ & $1412^{b}$ \\
\hline $\mathrm{Cr}_{2} \mathrm{O}_{3}$ & 3.9 & 4.4 & 3.9 & 5.4 \\
\hline
\end{tabular}

${ }^{1}$ Values (means of duplicate groups) in the same row not sharing a common superscript letter are significantly different $(P<0.05)$. 
Table III. Apparent digestibility coefficients (ADCs) of feed components by carp held at two different temperatures of 18 and $25^{\circ} \mathrm{C} . \mathrm{SPC}$, soy protein concentrate; FM, Norwegian herring meal.

\begin{tabular}{lccccc}
\hline $\begin{array}{l}\text { ADCs } \\
(\%)\end{array}$ & \multicolumn{2}{c}{ Diet $/ 18^{\circ} \mathrm{C}$} & & \multicolumn{2}{c}{ Diet $/ 25^{\circ} \mathrm{C}$} \\
\cline { 2 - 3 } \cline { 5 - 6 } & SPC & FM & & SPC & FM \\
\hline Dry matter & $74.4 \pm 0.30^{\mathrm{b}}$ & $75.6 \pm 0.55^{\mathrm{b}}$ & & $74.6 \pm 0.90^{\mathrm{b}}$ & $80.0 \pm 0.37^{\mathrm{a}}$ \\
Protein & $91.3 \pm 0.04^{\mathrm{b}}$ & $85.9 \pm 0.63^{\mathrm{c}}$ & & $93.3 \pm 0.55^{\mathrm{a}}$ & $90.8 \pm 0.15^{\mathrm{b}}$ \\
Lipid & $94.5 \pm 0.13^{\mathrm{a}}$ & $89.8 \pm 0.15^{\mathrm{b}}$ & & $96.0 \pm 1.45^{\mathrm{a}}$ & $96.4 \pm 0.56^{\mathrm{a}}$ \\
Ash & $25.6 \pm 1.31$ & $28.7 \pm 0.06$ & & $23.9 \pm 0.43$ & $30.1 \pm 2.85^{\mathrm{n}}$ \\
Ca & $15.6 \pm 0.13^{\mathrm{b}}$ & $30.2 \pm 0.26^{\mathrm{a}}$ & & $20.4 \pm 2.02^{\mathrm{b}}$ & $36.7 \pm 2.76^{\mathrm{a}}$ \\
P & $29.0 \pm 1.69^{\mathrm{b}}$ & $34.3 \pm 0.52^{\mathrm{a}}$ & & $25.9 \pm 1.37^{\mathrm{b}}$ & $34.6 \pm 1.13^{\mathrm{a}}$ \\
Energy & $82.9 \pm 0.30^{\mathrm{b}}$ & $81.6 \pm 0.36^{\mathrm{b}}$ & & $83.2 \pm 1.02^{\mathrm{b}}$ & $86.9 \pm 0.03^{\mathrm{a}}$ \\
\hline
\end{tabular}

' Values (means \pm SE of duplicate groups) in the same row not sharing a common superscript letter are significantly different $(P<0.05)$; ns $=$ non significant.

dry matter and of energy at $25^{\circ} \mathrm{C}$. At both temperatures, ADC of protein was higher in fish fed diet SPC than in those fed the other diet. Fish fed diet SPC had a higher ADC of lipid than the other groups at $18^{\circ} \mathrm{C}$; however, the value remained constant between the two groups at the higher temperature. Although the ADC for ash was not different between both groups under two temperatures, the availability of $\mathrm{Ca}$ and $\mathrm{P}$ was higher in fish fed diet FM than those fed diet SCP.

It is well-known that protein and energy digestibility coefficients are barely affected by water temperatures ranging from 7 to $18^{\circ} \mathrm{C}$ for rainbow trout $[4,5,18]$. However, the present results showed increased protein digestibility for both fish groups reared at a higher water temperature. Recently, Watanabe et al. [17] reported that an increase in temperature from 5 to $15^{\circ} \mathrm{C}$ resulted in improved protein digestibility of animal and plant feedstuffs for rainbow trout. Such an effect was, however, not found in carp held at 15, 20 and $25^{\circ} \mathrm{C}$ except for corn gluten meal and defatted rice bran whose ADC of protein increased from 82.4 to $93 \%$ and from 60.1 to $87.8 \%$, respectively. On the other hand, fish fed diet SPC composed of plant protein sources showed a significantly higher ADC than those fed the other diet at both temperatures. This suggests that soy protein concentrate could be use as a comparable substitute for fish meal in carp diets. Between the two groups held at $18{ }^{\circ} \mathrm{C}, \mathrm{ADC}$ of lipid was higher in fish fed diet SPC, but such a difference was not found at $25^{\circ} \mathrm{C}$. Because dietary lipid source was the same in both diets, the difference (94.5 vs. $89.8 \%$ ) at lower temperature remains to be explained. Despite the fact that diet SPC contained $4 \%$ dicalcium phosphate which was more utilisable than tribasic phosphate originating from body skeleton [13], ADCs of Ca and P for fish fed the SPC diet were inferior to those for the other groups at both temperatures. The variability in micronutrient availability induced by incorporation of plant protein sources has already been reported [12] and requires more attention.

\section{REFERENCES}

[1] Abel H.J., Becker K., Meske C., Friedrich W., Possibilities of using heat-treated full-fat soybeans in carp feeding, Aquaculture 42 (1984) 97-108.

[2] AOAC, Official Methods of Analysis, 14th ed., Association of Official Analytical Chemists, Airlington, Virginia, 1984, $1141 \mathrm{p}$.

[3] Bolin D.W., King R.P., Klosrerman W.W., A simplified method for the determination of chromic oxide when used an inert substance, Science 116 (1952) 634-635.

[4] Cho C.Y., Kaushik S.J., Nutritional energetics in fish: Energy and protein utilization in rainbow trout, World Rev. Nutr. Diet. 61 (1990) 132-172.

[5] Cho C.Y., Slinger S.J., Apparent digestibility measurement in feedstuffs for rainbow trout, in: Halver J.E., Tiews K. (Eds.), Finfish Nutrition and Fishfood Technology, vol. 2, Heenemann $\mathrm{GmbH}$, Berlin, 1979, pp. 239-247.

Aquat. Living Resour. 11 (4) (1998)
[6] Choubert G., De La Noue J., Luquet P., Un nouveau collecteur automatique quantitatif de feces de poissons, Bull. Fr. Piscic. 288 (1982) 68-72.

[7] Degani G., Yehuda Y., Viola S., Degani G., The digestibility of nutrient sources for common carp, Cyprinus carpio Linnaeus, Aquac. Res. 28 (1997) 575-580.

[8] Duncan D.B., Multiple range and multiple F tests, Biometrics 11 (1955) 1-42.

[9] Kaushik S.J., Cravedi J.P., Lalles J.P., Sumpter J., Fauconneau B., Laroche M., Partial or total replacement of fish meal by soybean proetin on growth, protein utilization, potential estrogenic or antigenic effects, cholesterolemia and flesh quality in rainbow trout, Oncorhynchus mykiss, Aquaculture 133 (1995) 257274.

[10] Kim J.D., Ahn K.H., Effect of monocalcium phosphate supplementation on phosphorus discharge and growth of carp grower, Asian-Australasian J. Anim. Sci. 6 (1993) 521-526. 
[11] Kirchgessner M., Kurzinger H., Schwartz F.J., Digestibility of crude nutrients in different feed and estimation of their energy content for carp, Aquaculture 58 (1986) 185-194.

[12] NRC, Nutrient requirements of fish, National Academy Press, Washington DC, 1993, 114p.

[13] Ogino C., Takeuchi L, Takeda H., Watanabe T., Availability of dietary phosphorus in carp and rainbow trout, Nippon Suisan Gakkaishi 45 (1979) 1527-1532.

[14] Plakas S.M., Katayama T., Apparent digestibilities of amino acids from three regions of the gastrointestinal tract of carp (Cyprinus carpio) after ingestion of a protein and a corresponding free amino acid diet, Aquaculture 24 (1981) 309-314.
[15] Pongmaneerat J., Watanabe T., Nutritive value of protein of feed ingredients for carp, Nippon Suisan Gakkaishi 57 (1991) 503-510.

[16] Pongmaneerat J., Watanabe T., Takeuchi T., Satoh S., Use of different protein meals as partial or total substitution for fish meal in carp diets, Nippon Suisan Gakkaishi 59 (1993) 1249-1257.

[17] Watanabe T., Takeuchi T., Satoh S., Kiron V., Digestible crude protein contents in various feedstuffs determined with four freshwater fish species, Fish. Sci. 62 (1996) 278-282.

[18] Windell J.T., Foltz J.W., Sarokon J.A., Effect of body size, temperature and ration size on the digestibility of a dry pelleted diet by rainbow trout, Trans. Am. Fish. Soc. 107 (1978) 613-616. 